Article

\title{
Building Automation and Control Systems and Electrical Distribution Grids: A Study on the Effects of Loads Control Logics on Power Losses and Peaks
}

\author{
Salvatore Favuzza, Mariano Giuseppe Ippolito, Fabio Massaro, Rossano Musca, \\ Eleonora Riva Sanseverino, Giuseppe Schillaci and Gaetano Zizzo * (D) \\ Department of Energy, Information Engineering and Mathematical Models, Università di Palermo, \\ 90128 Palermo, Italy; salvatore.favuzza@unipa.it (S.F.); marianogiuseppe.ippolito@unipa.it (M.G.I.); \\ fabio.massaro@unipa.it (F.M.); rossanomusca@msn.com (R.M.); eleonora.rivasanseverino@unipa.it (E.R.S.); \\ g.schillaci84@virgilio.it (G.S.) \\ * Correspondence: zizzo@dieet.unipa.it or gaetano.zizzo@unipa.it; Tel.: +39-091-23860205
}

Received: 12 February 2018; Accepted: 13 March 2018; Published: 15 March 2018

\begin{abstract}
Growing home comfort is causing increasing energy consumption in residential buildings and a consequent stress in urban medium and low voltage distribution networks. Therefore, distribution system operators are obliged to manage problems related to the reliability of the electricity system and, above all, they must consider investments for enhancing the electrical infrastructure. The purpose of this paper is to assess how the reduction of building electricity consumption and the modification of the building load profile, due to load automation, combined with suitable load control programs, can improve network reliability and distribution efficiency. This paper proposes an extensive study on this issue, considering various operating scenarios with four load control programs with different purposes, the presence/absence of local generation connected to the buildings and different external thermal conditions. The study also highlights how different climatic conditions can influence the effects of the load control logics.
\end{abstract}

Keywords: Building Automation and Control (BAC); demand-side management; demand-side management (DSM); demand response; load control; power losses

\section{Introduction}

Increasing home comfort is causing increased energy consumption in residential buildings and consequent stress on cities' medium and low voltage (LV) networks [1-3]. For this reason, Distribution System Operators (DSOs) have to manage problems related to the reliability of the power system and, above all, they must plan new investments for enforcing the electrical infrastructure [4,5]. Nevertheless, in general, DSOs tend to postpone this kind of investment, preferring more flexible measures for mitigating the effects of the growing consumption and, at the same time, for increasing the technical life of the existing infrastructure. These measures are mainly based on demand-side management (DSM), that is, activities aimed at encouraging end-users to engage in smart energy utilization $[6,7]$. DSM has a large number of benefits for distribution systems: for example, it may slow down the annual peak load growth rate, decrease the overall energy consumption due to the building sector, reduce power system losses, decrease greenhouse gas (GHGs) emissions due to buildings' load usage and, finally, postpone investments for enhancing the power distribution grid. In this context, the proposed paper investigates the effects on the distribution grid of some control logics (defined in Reference [8]) implemented in Building Automation and Control (BAC) systems for residential buildings also in the presence of distributed generation from renewable energy sources (RESs).

With regards to similar studies in the literature, some recent research has examined the impact of distributed generation (DG) on power losses, reliability improvement and voltage stability $[9,10]$. 
In Reference [11], an analysis of load flexibility for providing grid services is presented, while in Reference [12], the influence of emergency demand response (DR) programs in improving reliability in case of the failure of generation units is investigated. In Reference [13] the authors examine the role of DR in supporting system stability through fully remote-controlled (by the grid operator) shifts of individual processes in households and in the commercial and industrial sectors.

In Reference [14] the authors examine the impact on the power distribution grid of some energy efficiency measures in buildings. Three types of measures are considered: reduction of the thermal transmittance of the opaque envelope, reduction of the thermal transmittance of the glazed envelope and installation of high-efficiency air-conditioning systems instead of the existing ones. The above measures are applied to different building typologies (residential, industrial and school). The impact on the grid is evaluated considering that all buildings belonging to the same typology have the same load profiles and not considering the possible shifting of the load profiles due to the different energy behaviours of the end-users. Finally, the impact on the grid in terms of power losses reduction is evaluated using the software NEPLAN [15].

In Reference [16] the authors focus on the impact on urban districts of decarbonizing the electric grid supply, by the analysis of a number of scenarios corresponding to different levels of renewable energy share in the electricity grid. The analysis is carried out, solving a multi-objective optimization problem aimed at minimizing the total cost of the heat and electricity generation plants and total GHG emissions. The impact on the distribution grid is evaluated for each scenario with reference to the IEEE European LV Test Feeder case [17] and considering the aggregated branch current and phase-to-neutral voltages. The same authors, in Reference [18], investigate the possibility of mitigating the negative impact of DG on the power distribution grid by properly designing and determining operation strategies of distributed resources.

Many papers address the impact on the electrical grid of battery energy storage systems connected to buildings in terms of the compensation of peak power demand, power quality, reliability improvements, the reduction of supply interruption, and load following to enhance generation utilization [19-23]. In Reference [24], the authors discuss the various challenges of distribution grids with the integration of energy storage systems and renewable energy sources exploring the importance of DSM and Time of Use pricing. In Reference [25] the authors propose a stochastic DSM for supporting the integration of battery energy storage systems and electric vehicles into distribution grids.

The IEA EBC Annex 67, "Energy Flexible Buildings", also considers the effects on the power grid of a building's flexibility [26] among their working activities.

As shown in the literature review above, few papers focus on the impact of DSM on power losses and power peaks in power distribution systems. Therefore, the novelty of the present paper, that expands the research presented in [27], is the analysis of the correlation between demand-side load control logic and the effects on the distribution grid in terms of the reduction of power losses, the reduction of power peaks and deferral in time for investments to empower the network infrastructure. This paper examines a scenario in which automation is diffused among all the end-users and evaluates the impact on the grid of each control logic defined in Reference [8], both in the presence and the absence of DG and for different temperature profiles, depending on the building's location. Indeed, as shown in Reference [8], the external temperature has a significant influence on the operation of the air-conditioning system and on the related electricity consumption.

The rest of the paper is structured as it follows: in Section 2 the load control logics considered in the simulations are briefly summarized; in Section 3 the model and data used in the study are presented, and the simulation results for three different locations in Italy (Palermo, Rome and Turin) are reported; and finally, Section 4 contains the conclusions of the paper.

\section{Control Logics for Demand Side Management}

The work in Reference [8] illustrates some innovative control logics designed to manage the electrical loads in a house, taking into account the effects of the external temperature on 
the consumption of the air-conditioning system. The automation system considered in Reference [8] manages the air-conditioners, the lighting system and some other shiftable loads such as the electric storage water heater, the washing machine and the dishwasher, in order to accomplish different tasks that can be chosen by the end-user. For every task, the end-user selects a well-defined control logic, according to the descriptions in Table 1. Given the aim of the present work, no further details are provided on the four control logics, the operation, implementation and validation of which have been discussed in Reference [8].

Table 1. Load control logics.

\begin{tabular}{|c|c|c|}
\hline Control Logic & Description & Task \\
\hline Comfort & $\begin{array}{l}\text { All the electric loads of the house are supplied and maximum comfort } \\
\text { is guaranteed in terms of internal temperature and usage possibility. } \\
\text { The controllable loads are managed in order not to exceed } \\
\text { the maximum available power, ensuring the continuity of supply. }\end{array}$ & $\begin{array}{l}\text { Maximum comfort } \\
\text { Maximum continuity of supply }\end{array}$ \\
\hline Economy & $\begin{array}{l}\text { The minimum purchase cost of electricity to the user is always } \\
\text { guaranteed. The house energy management system (EMS), every ten } \\
\text { minutes, optimally configures the loads' supply to ensure both } \\
\text { the minimum expense for electricity and a complete compliance with } \\
\text { the constraints of the power system. }\end{array}$ & Minimum expense for electricity \\
\hline Energy & $\begin{array}{l}\text { A pre-established threshold of energy consumption or the daily } \\
\text { economic expenditure for electricity is not exceeded. The user decides } \\
\text { the threshold and the time period (one day, one week, etc.). EMS } \\
\text { notifies the user of the average daily consumption allowed to reach } \\
\text { the set target }\end{array}$ & $\begin{array}{l}\text { Maintain energy consumption } \\
\text { below a given threshold }\end{array}$ \\
\hline Net-Service & $\begin{array}{l}\text { This logic allows the DSO to manage the controllable loads of } \\
\text { the house in a fixed period of time. Therefore, the DSO can mitigate } \\
\text { the power peak of the user load diagram. The user can choose one of } \\
\text { the control logics listed above to achieve specific targets (i.e., energy } \\
\text { saving, economic saving). }\end{array}$ & $\begin{array}{l}\text { Allow the DSO to manage } \\
\text { controllable loads consumption }\end{array}$ \\
\hline
\end{tabular}

As an example of the operation of the above-described control logics, Figure 1 shows the daily power profiles for a typical summer day in an apartment in Palermo (South Italy), characterized by the loads presented in Table 2. The graphs in Figure 1 clearly show how the control logics are able to substantially modify the load profile of the apartment.

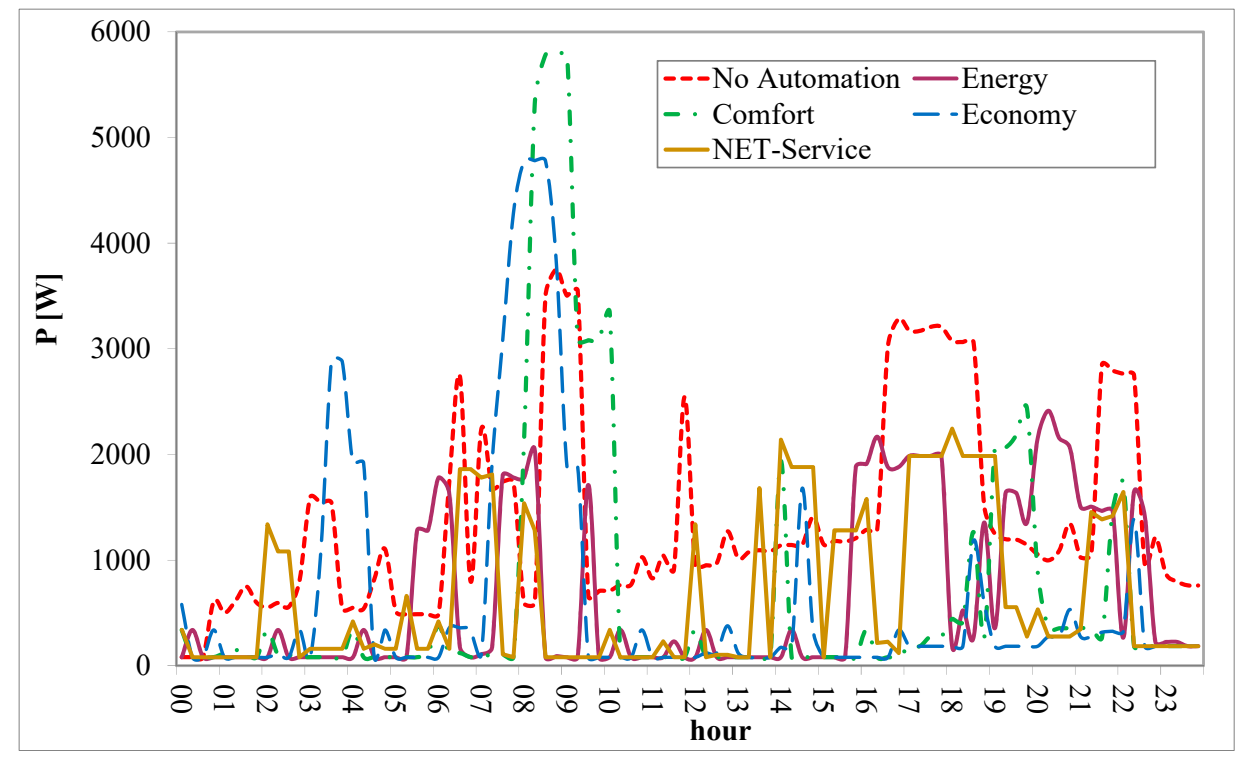

Figure 1. Daily power profiles for an apartment, modified by the action of the control logics. 
Table 2. Electric loads in the apartment.

\begin{tabular}{cc}
\hline Electric Load & Installed Power (W) \\
\hline Living room lighting & 114 \\
Kitchen lighting & 36 \\
Toilet lighting & 100 \\
2nd Toilet lighting & 100 \\
Main bedroom lighting & 100 \\
Small bedroom lighting & 100 \\
\hline Polisher & 1000 \\
Hair dryer & 1200 \\
Electric iron & 1500 \\
Electric oven & 2000 \\
Microwave oven & 2000 \\
Fridge-Freezer & 250 \\
Dishwasher & 2000 \\
Washing Machine & 2000 \\
Balanced Ventilation System & 400 \\
Exhaust fan & 150 \\
\hline PC & 70 \\
HI-FI & 200 \\
\hline TV, VCR and DVD player & 150 \\
\hline Electric Storage Water Heater & 1200 \\
\hline
\end{tabular}

\section{Evaluation of the Impacts on the Distribution Network}

\subsection{Model of the Network}

For the evaluation of the impact of the control logics on the distribution grid, a computer simulation was performed on a test network implemented in a NEPLAN v. 553 [15] environment, the topology of which is shown in Figure 2.

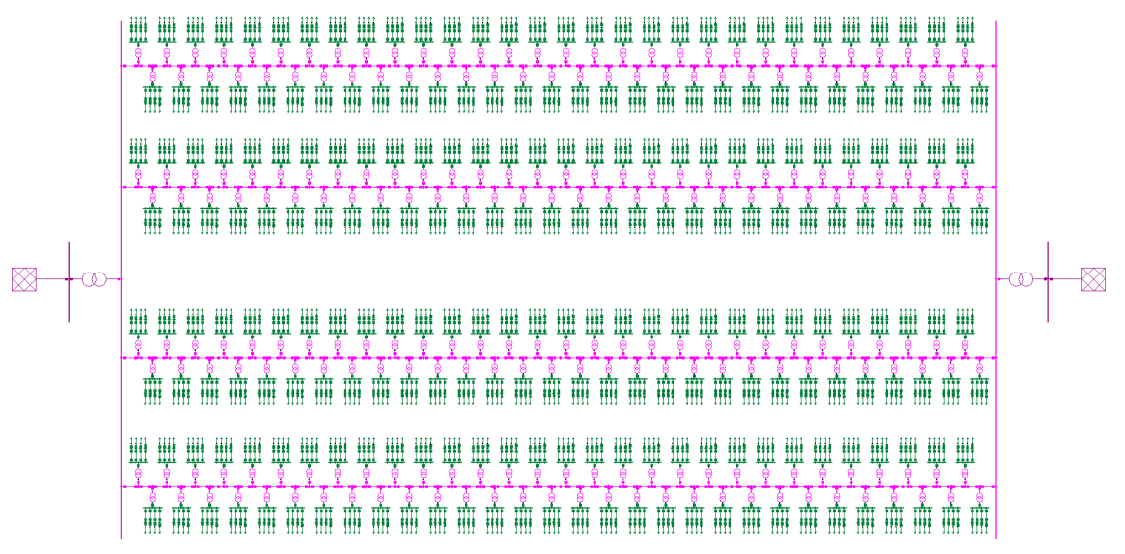

Figure 2. Test-Network.

The network, representing a classical scheme adopted in urban areas, comprises the following elements:

- 1444 medium voltage (MV) and low voltage buses;

- 2 primary (high voltage to medium voltage) stations, each one containing a 40 MVA rated power transformer;

- $240 \mathrm{MV} / \mathrm{LV}$ transformers (400 kVA each);

- $4 \mathrm{MV}$ cable lines (cable section $240 \mathrm{~mm}^{2}$, color purple);

- $\quad$ LV cable lines (cable section $95 \mathrm{~mm}^{2}$, color green). 
LV lines feed residential user groups only. The loads listed in Table 2 are considered installed at every user's facility.

The software allows implementation of the demand management logic for each individual load. The daily load profiles of residential users were calculated using a Monte Carlo approach using the software presented in Reference [8]. NEPLAN allows, through a special editor, the creation of very complex load profiles:

- hourly level;

- seasonal level—articulating the load profiles changing trends for seasonal scales;

- annual level—entering the trend of growth or decrease in power consumption every year.

\subsection{Simulation Results}

The simulations of the system shown in Figure 2 were carried out in three different metropolises: Turin (Northern Italy, Latitude $45.06 \mathrm{~N}$, Altitude $211 \mathrm{~m}$ ), Rome (Central Italy, Latitude $41.53 \mathrm{~N}$, Latitude $52 \mathrm{~m}$ ) and Palermo (Southern Italy, Latitude $38.07 \mathrm{~N}$, Altitude $46 \mathrm{~m}$ ). Latitude and altitude influence the climatic data used by the simulator to estimate the daily consumption for cooling and heating and, therefore, for the simulation of the air-conditioning system. Table 3 reports the maximum summer and minimum winter temperatures for the three cities considered in the simulations, according to the Italian Standard UNI 10349 [28].

Latitude also influences the irradiation values used for the calculation of the daily production of energy by a photovoltaic (PV) generator connected to the house.

Table 3. Maximum summer and minimum winter external temperatures.

\begin{tabular}{ccc}
\hline City & Maximum Summer Temperature $\left[{ }^{\circ} \mathrm{C}\right]$ & Minimum Winter Temperature $\left[{ }^{\circ} \mathbf{C}\right]$ \\
\hline Rome & 32 & 5 \\
Palermo & 33 & 0 \\
Turin & 30.5 & -8 \\
\hline
\end{tabular}

Finally, according to the Italian Decree DPR 412/93 [29], the duration of the daily activation time during winter of the air-conditioning system varies for the three cities, as shown below:

- Palermo: Heating period: 1 December-31 March; Duration of the activation time $8 \mathrm{~h} /$ day;

- Rome: Heating period: 1 November-15 April; Duration of the activation time $12 \mathrm{~h} /$ day;

- Turin: Heating period: 15 October-15 April; Duration of the activation time $14 \mathrm{~h} /$ day.

The same Decree does not give useful indications for estimating the activation time of the air-conditioning system during summer. Therefore, for the three cities, an equal activation time of 8 hours per day has been assumed.

The average daily load diagrams (summer and winter) of a typical house, as reported in Reference [8], were determined both in the presence and absence of a $3 \mathrm{~kW} \mathrm{PV}$ generator. The production of the generator for every season and location was calculated assuming the daily irradiation data from the Joint Research Centre Photovoltaic Geographical Information System (JRC PVGIS) Database [30].

The diagrams were calculated for the following scenarios:

- S.0-Traditional (without automation);

- $\quad$ S.1-Comfort;

- S.2-Economy;

- $\quad$ S.3-Energy;

- $\quad$ S.4-Net-Service. 
The following assumptions were made for simulating the effects of the control logics:

- in every scenario, the Building Management System (BMS) of each apartment is able to manage the following loads: air-conditioning system, lighting system, dishwasher, washing machine;

- the power demand of the air-conditioning system can be modulated by acting on the temperature set-point but without disturbing significantly the inhabitants' comfort;

- the lighting system can be controlled by switching off the light in the absence of people in a room or by making it follow natural light for assuring a minimum illuminance value in all the occupied rooms;

- dishwasher and washing machine activation time can be shifted in time according to the need of the BMS;

- in the Comfort scenario, the maximum power demand for each apartment was set equal to $4.5 \mathrm{~kW}$ (ordinary residential users in Italy with air-conditioners and electric storage water heater);

- in the Economy scenario, the three pricing periods named F1, F2, and F3, according to Italian regulation [31] were considered. F1 comprises weekdays from 8:00 to 19:00 (electricity cost $0.076 € / \mathrm{kWh}$ ); F2 comprises weekdays from 7:00 to 8:00 and from 19:00 to 23.00 and Saturday from 7:00 to 11:00 (electricity cost $0.063 € / \mathrm{kWh}$ ); F3 comprises all remaining hours in a week and holidays (currently it has the same electricity cost of F2 for residential users);

- in the Energy scenario, the threshold for the daily energy consumption was set to $11 \mathrm{kWh}$;

- in the Net-Service scenario, the threshold for the maximum power demand was set equal to $2 \mathrm{~kW}$ for each apartment.

Figures 3-5 represent the daily load diagrams of one of the primary substations for a typical summer (S) and winter (W) day, both in the presence (FV) and in the absence (NFV) of photovoltaic generators. To simplify the study, spring and autumn have not been evaluated, considering that the proposed control logics mainly act on the air-conditioning system of the house, not used during intermediate seasons.

The results of the simulations carried out for a time interval of one year on the test network are shown in Tables 4-9. The tables report some values useful for evaluating the impact of each control logic on the total energy consumption of the buildings and on the energy losses in the network. Although Tables 4-9 provide sufficient information regarding the effects of the control logics, Figures 3-5 are reported as an example of how the control logics modify the shape of the daily power profile. With reference to the power peak, for example, the considered control logics sometimes reduce the daily power peak, sometimes they shift it to a different hour and sometimes they increase it (for example as an effect of the Economy control logic that, reducing the daily cost for energy purchase, creates a concentration of loads in the F2/F3 pricing period). 


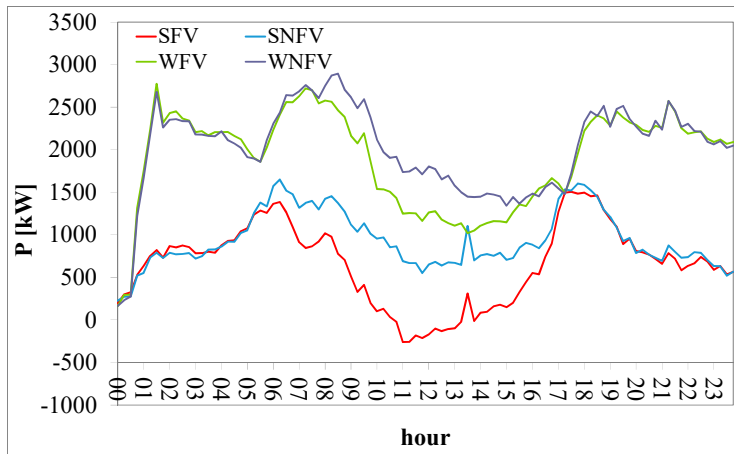

S.0-Traditional

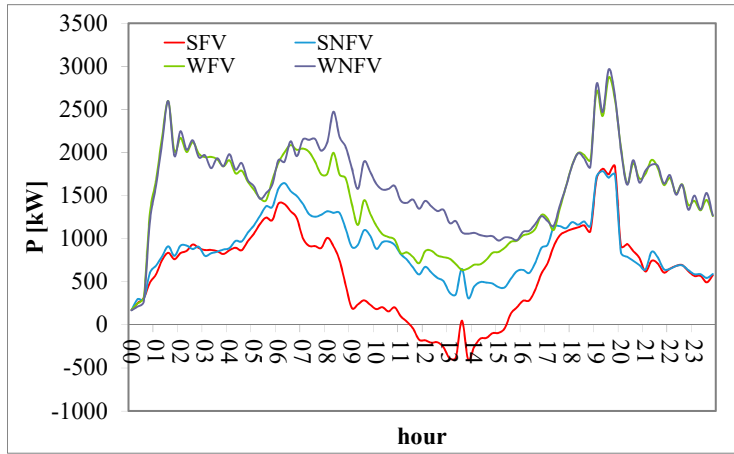

S.2-Economy

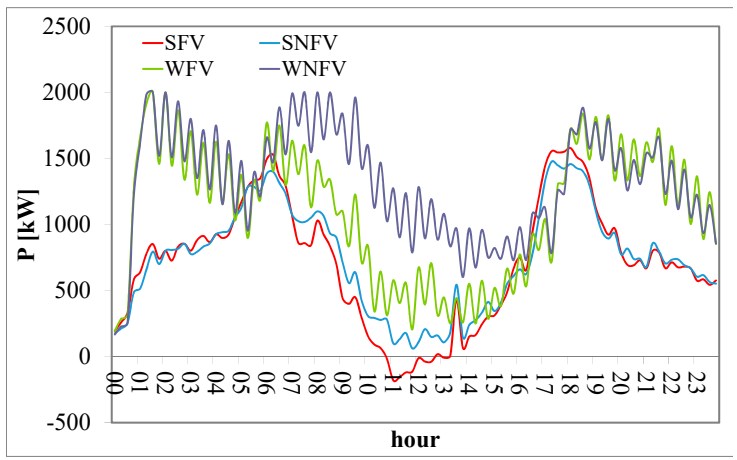

S.4-Net-servicee

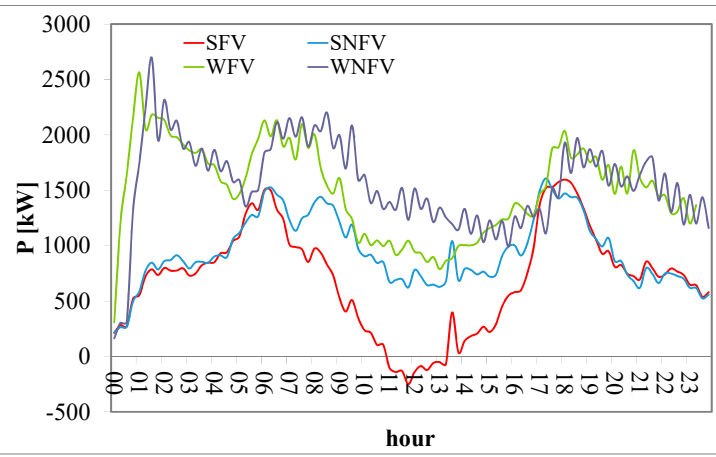

S.1-Comfort

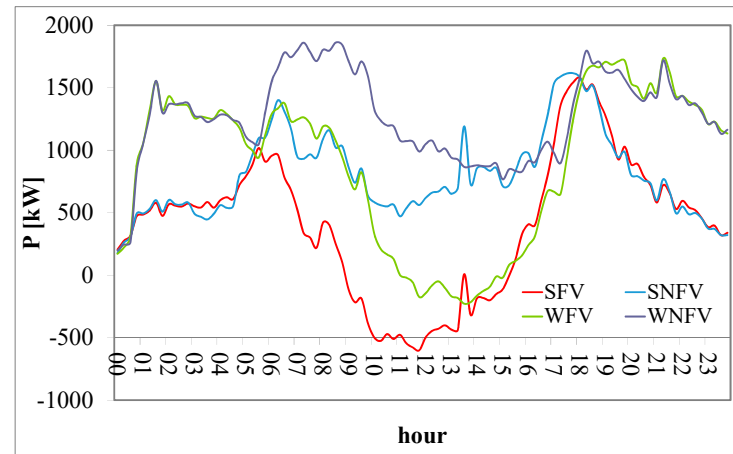

S.3-Energy

Figure 3. Turin: daily power profile at a primary substation for Scenarios S.0 to S.4.

Table 4. Turin-Energy consumptions and losses for the different control logics (No PV).

\begin{tabular}{ccccc}
\hline Scenario & $\begin{array}{c}\text { EY }_{\mathbf{Y}} \text { Yearly Energy } \\
\text { Consumption of } \\
\text { the Buildings [MWh] }\end{array}$ & $\begin{array}{c}\text { Reduction of } \mathrm{E}_{\mathbf{Y}} \text { with } \\
\text { Respect to the Base } \\
\text { Case (No Automation) }\end{array}$ & $\begin{array}{c}\Delta \mathrm{E}_{\mathbf{Y}}: \text { Yearly } \\
\text { Energy Losses on } \\
\text { the Grid [MWh] }\end{array}$ & $\begin{array}{c}\text { Reduction } \Delta \mathrm{E}_{\mathbf{Y}} \text { with } \\
\text { Respect to the Base Case } \\
\text { (No Automation) }\end{array}$ \\
\hline S.0 & 373,096 & - & 7792 & - \\
S.1 & 315,974 & $15.31 \%$ & 6010 & $22.87 \%$ \\
S.2 & 317,564 & $14.88 \%$ & 6262 & $19.64 \%$ \\
S.3 & 260,886 & $30.08 \%$ & 4987 & $36.00 \%$ \\
S.4 & 259,784 & $30.37 \%$ & 5145 & $33.97 \%$ \\
\hline
\end{tabular}


Table 5. Turin-Energy consumptions and losses for the different control logics (Presence of FV).

\begin{tabular}{ccccc}
\hline Scenario & $\begin{array}{c}\mathrm{E}_{\mathbf{Y}} \text { : Yearly Energy } \\
\text { Consumption of } \\
\text { the Buildings [MWh] }\end{array}$ & $\begin{array}{c}\text { Reduction of } \mathrm{E}_{\mathbf{Y}} \text { with } \\
\text { Respect to the Base } \\
\text { Case (No Automation) }\end{array}$ & $\begin{array}{c}\Delta \mathrm{E}_{\mathbf{Y}}: \text { Yearly } \\
\text { Energy Losses on } \\
\text { the Grid [MWh] }\end{array}$ & $\begin{array}{c}\text { Reduction } \Delta \mathrm{E}_{\mathbf{Y}} \text { with } \\
\text { Respect to the Base Case } \\
\text { (No Automation) }\end{array}$ \\
\hline S.0 & 325187 & - & 7066 & - \\
$\mathrm{S} .1$ & 277702 & $14.60 \%$ & 5594 & $20,83 \%$ \\
$\mathrm{~S} .2$ & 271472 & $16.52 \%$ & 5676 & $19,66 \%$ \\
$\mathrm{~S} .3$ & 161344 & $50.38 \%$ & 4273 & $39,52 \%$ \\
S.4 & 230448 & $29.13 \%$ & 4769 & $32,50 \%$ \\
\hline
\end{tabular}

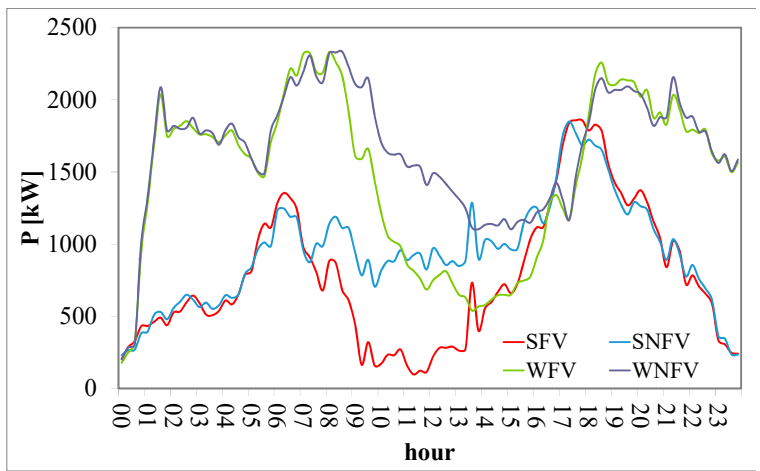

S.0-Traditional

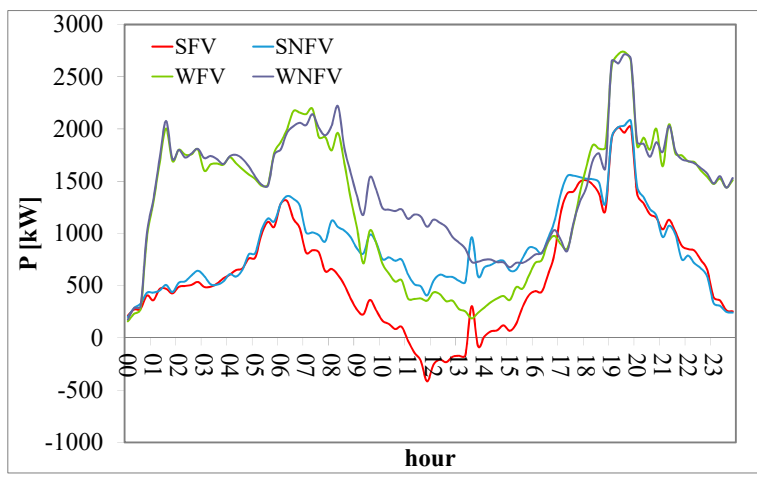

S.2-Economy

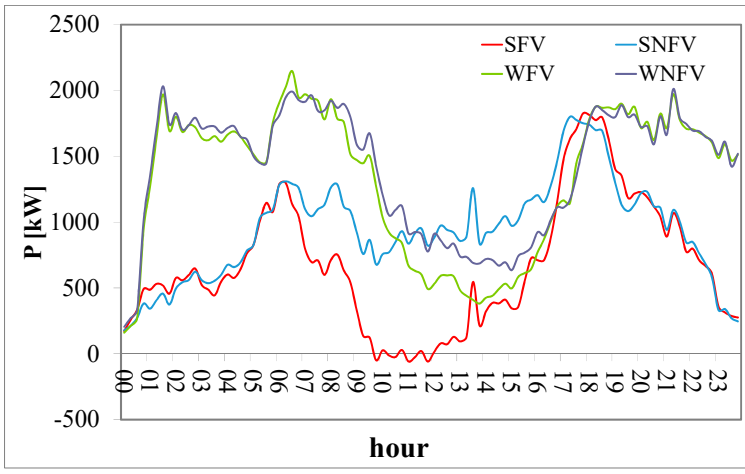

S.1-Comfort

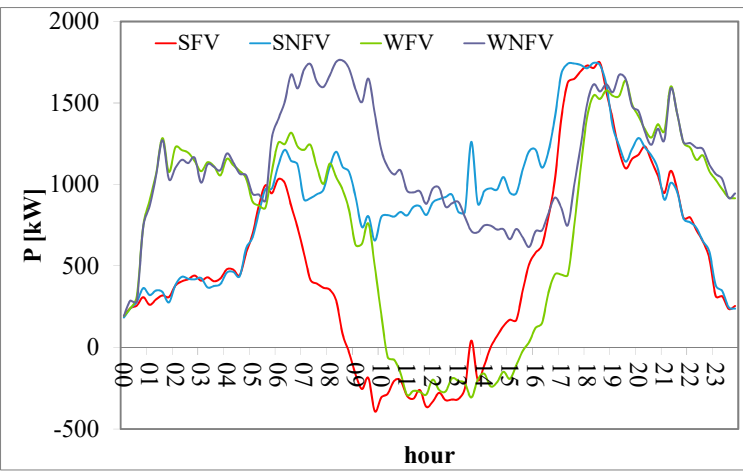

S.3-Energy

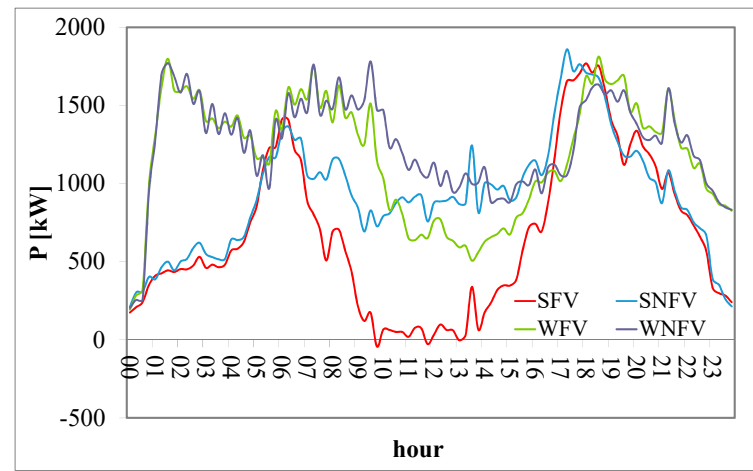

S.4-Net-service

Figure 4. Rome: daily power profile at a primary substation for Scenarios S.0 to S.4. 


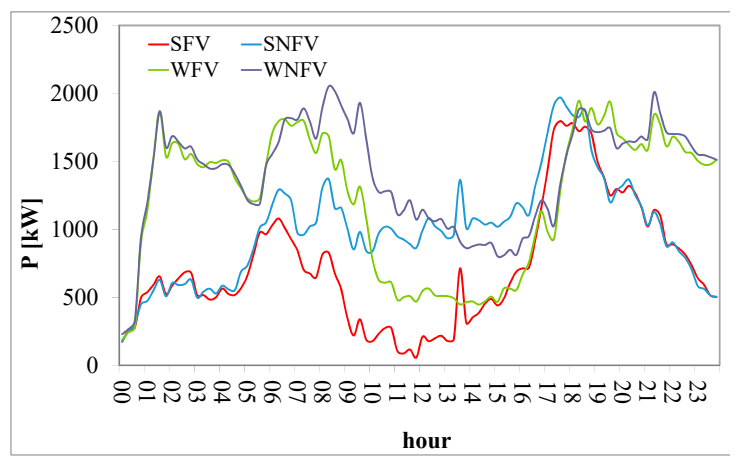

S.0-Traditional

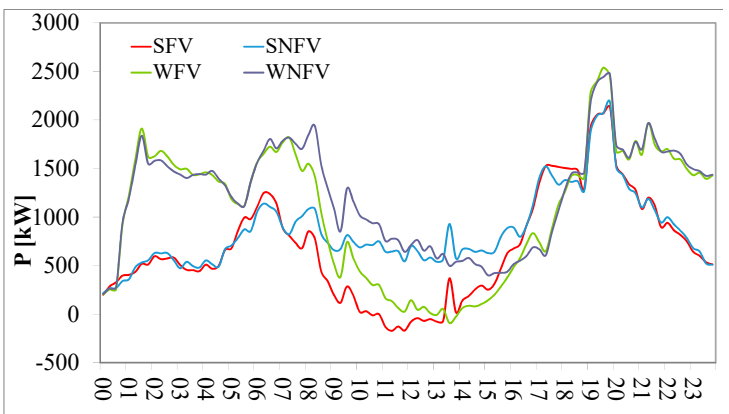

hour

S.2-Economy

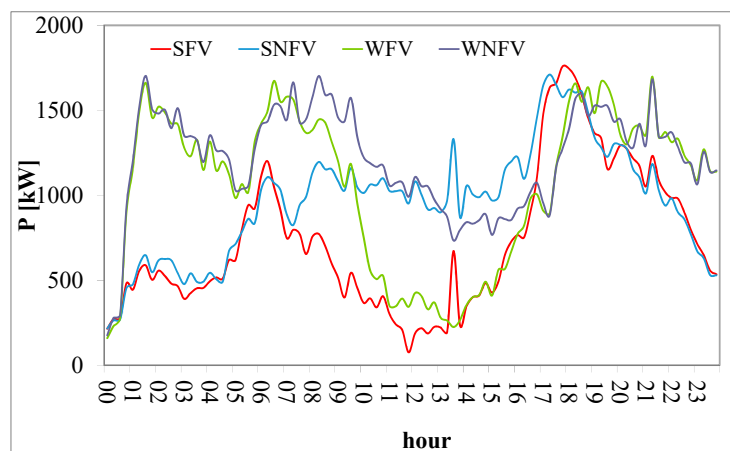

S.4-Net-service

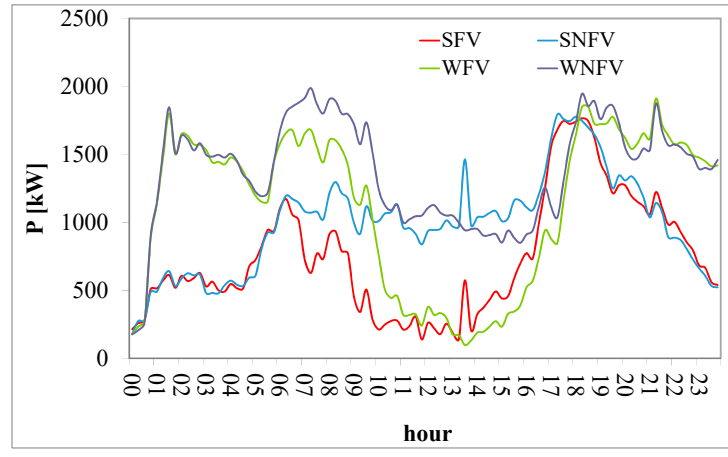

S.1-Comfort

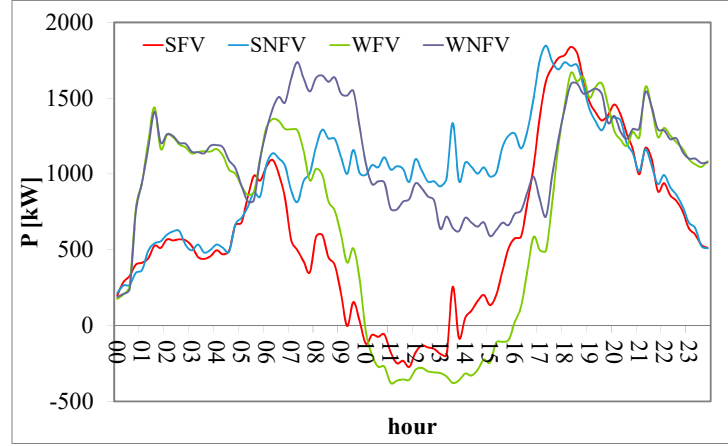

S.3-Energy

Figure 5. Palermo: daily power profile at a primary substation for Scenarios S.0 to S.4.

Table 6. Rome: Energy consumptions and losses for the different control logics (No PV).

\begin{tabular}{ccccc}
\hline Scenario & $\begin{array}{c}\text { EY: Yearly Energy } \\
\text { Consumption of } \\
\text { the Buildings [MWh] }\end{array}$ & $\begin{array}{c}\text { Reduction of EY with } \\
\text { Respect to the Base } \\
\text { Case (No Automation) }\end{array}$ & $\begin{array}{c}\Delta E_{\mathbf{Y}}: \text { Yearly } \\
\text { Energy Losses on } \\
\text { the Grid [MWh] }\end{array}$ & $\begin{array}{c}\text { Reduction } \Delta \mathrm{E}_{\mathbf{Y}} \text { with } \\
\text { Respect to the Base Case } \\
\text { (No Automation) }\end{array}$ \\
\hline S.0 & 326,824 & - & 6336 & - \\
S.1 & 295,681 & $9.53 \%$ & 5595 & $11.69 \%$ \\
S.2 & 292,800 & $10.41 \%$ & 5785 & $8.69 \%$ \\
S.3 & 255,061 & $21.96 \%$ & 4865 & $23.21 \%$ \\
S.4 & 275,171 & $15.80 \%$ & 5128 & $19.06 \%$ \\
\hline
\end{tabular}


Table 7. Rome: Energy consumptions and losses for the different control logics (Presence of FV).

\begin{tabular}{ccccc}
\hline Scenario & $\begin{array}{c}\mathbf{E}_{\mathbf{Y}} \text { : Yearly Energy } \\
\text { Consumption of } \\
\text { the Buildings [MWh] }\end{array}$ & $\begin{array}{c}\text { Reduction of } \mathrm{E}_{\mathbf{Y}} \text { with } \\
\text { Respect to the Base } \\
\text { Case (No Automation) }\end{array}$ & $\begin{array}{c}\Delta \mathrm{E}_{\mathbf{Y}}: \text { Yearly } \\
\text { Energy Losses on } \\
\text { the Grid [MWh] }\end{array}$ & $\begin{array}{c}\text { Reduction } \Delta \mathrm{E}_{\mathbf{Y}} \text { with } \\
\text { Respect to the Base Case } \\
\text { (No Automation) }\end{array}$ \\
\hline S.0 & 283,329 & - & 5817 & - \\
S.1 & 252,225 & $10.98 \%$ & 5277 & $9.29 \%$ \\
S.2 & 245,176 & $13.47 \%$ & 5371 & $7.67 \%$ \\
S.3 & 153,798 & $45.72 \%$ & 4146 & $28.73 \%$ \\
S.4 & 230,207 & $18.75 \%$ & 4751 & $18.32 \%$ \\
\hline
\end{tabular}

Table 8. Palermo-Energy consumptions and losses for the different control logics (No PV).

\begin{tabular}{ccccc}
\hline Scenario & $\begin{array}{c}\mathbf{E}_{\mathbf{Y}}: \text { Yearly Energy } \\
\text { Consumption of } \\
\text { the Buildings [MWh] }\end{array}$ & $\begin{array}{c}\text { Reduction of } \mathrm{E}_{\mathbf{Y}} \text { with } \\
\text { Respect to the Base } \\
\text { Case (No Automation) }\end{array}$ & $\begin{array}{c}\Delta \mathrm{E}_{\mathbf{Y}}: \text { Yearly } \\
\text { Energy Losses on } \\
\text { the Grid [MWh] }\end{array}$ & $\begin{array}{c}\text { Reduction } \Delta \mathrm{E}_{\mathbf{Y}} \text { with } \\
\text { Respect to the Base Case } \\
\text { (No Automation) }\end{array}$ \\
\hline S.0 & 302,317 & - & 5677 & - \\
S.1 & 298,338 & $1.32 \%$ & 5583 & $1.65 \%$ \\
S.2 & 261,969 & $13.35 \%$ & 5178 & $8.79 \%$ \\
S.3 & 264,114 & $12.64 \%$ & 4943 & $12.92 \%$ \\
S.4 & 275,000 & $9.04 \%$ & 5071 & $10.67 \%$ \\
\hline
\end{tabular}

Table 9. Palermo-Energy consumptions and losses for the different control logics (Presence of FV).

\begin{tabular}{ccccc}
\hline Scenario & $\begin{array}{c}\text { EY: Yearly Energy } \\
\text { Consumption of } \\
\text { the Buildings [MWh] }\end{array}$ & $\begin{array}{c}\text { Reduction of E } \\
\text { Respect to the Base } \\
\text { Case (No Automation) }\end{array}$ & $\begin{array}{c}\Delta E_{Y}: \text { Yearly } \\
\text { Energy Losses on } \\
\text { the Grid [MWh] }\end{array}$ & $\begin{array}{c}\text { Reduction } \Delta E_{Y} \text { with } \\
\text { Respect to the Base Case } \\
\text { (No Automation) }\end{array}$ \\
\hline S.0 & 244,866 & - & 5008 & - \\
S.1 & 236,192 & $3.54 \%$ & 4896 & $2.23 \%$ \\
S.2 & 221,004 & $9.74 \%$ & 4930 & $1.54 \%$ \\
S.3 & 166,745 & $31.90 \%$ & 4265 & $14.83 \%$ \\
S.4 & 224,473 & $8.33 \%$ & 4583 & $8.47 \%$ \\
\hline
\end{tabular}

As is clear from the results presented in the tables, each scenario allows for a reduction in electricity losses in the grid, which is lowest in the case of S.2-Economy. This scenario's final aim is to obtain a reduction in the cost of electricity for the user and not a reduction in consumption, shifting the loads to the period of the cheapest price of the day. The Comfort (S.1) and Energy (S.3) scenarios work by levelling the loads, obtaining, thanks to the mitigation of the power peaks, a substantial reduction in energy losses in the network. This reduction is generally higher in the presence of PV generators.

The Net-Service has to be considered an "emergency" scenario, applicable for short periods except in the case of deferment of investments for the power supply of the network. In this case, the decrease in energy losses is approximately equal to that of the Energy scenario.

Power loss reduction increases from South to North: this is due to the fact that in Turin, particularly on a typical winter day, the losses in the traditional scenario are very high because the energy demand is very high for heating. Moving from conventional heat pump control to power modulation, controlled by the Decision Support and Energy Management System (DSEMS), a very significant reduction in losses was achieved.

This reduction in the network's energy losses generates a significant economic impact which, in fact, represents an incentive for distributors. Tables 10 and 11 show the economic savings for TWh (with and without PV) considering a cost of $0.19 € / \mathrm{kWh}$ for $\mathrm{LV}$ electricity. 
Table 10. Economic saving due to the reduction of the energy losses in the grid (No PV).

\begin{tabular}{cccc}
\hline Scenario & North Turin [€/TWh] & Centre Rome [€/TWh] & South Palermo [€/TWh] \\
\hline Comfort & 1071 & 476 & 60 \\
Economy & 915 & 358 & 362 \\
Energy & 2043 & 1096 & 528 \\
Net service & 1936 & 834 & 419 \\
\hline
\end{tabular}

Table 11. Economic saving due to the reduction of the energy losses in the grid (presence of PV).

\begin{tabular}{cccc}
\hline Scenario & North Turin [€/TWh] & Centre Rome [€/TWh] & South Palermo [€/TWh] \\
\hline Comfort & 1007 & 407 & 90 \\
Economy & 972 & 346 & 66 \\
Energy & 3289 & 2065 & 847 \\
Net service & 1894 & 880 & 359 \\
\hline
\end{tabular}

Tables 10 and 11 show that the action of the four control logics leads to a reduction of the operative costs of the grid; the highest economic saving is obtained for Turin in the Energy scenario with PV systems.

It is worth underlining that, in Italy, energy loss reduction in distribution systems is financially supported through the so-called Energy Efficiency Certificates mechanism, which is a further boost for the DSOs for the promotion of load control actions.

The decrease in annual energy consumption and energy losses also allows a reduction of $\mathrm{CO}_{2}$ emissions into the atmosphere, assessed on the basis of Reference [32] and reported in Tables 12-14 for the three different locations.

Table 12. Turin $-\mathrm{CO}_{2}$ emission reduction with respect to the traditional scenario (S.0).

\begin{tabular}{ccc}
\hline \multirow{2}{*}{ Scenario } & \multicolumn{2}{c}{ Annual $\mathbf{C O}_{\mathbf{2}}$ Emission Reduction } \\
\cline { 2 - 3 } & Absence of PV Systems & Presence of PV Systems \\
\hline Comfort & $15 \%$ & $15 \%$ \\
Economy & $15 \%$ & $17 \%$ \\
Energy & $30 \%$ & $50 \%$ \\
Net service & $30 \%$ & $28 \%$ \\
\hline
\end{tabular}

Table 13. Rome- $-\mathrm{CO}_{2}$ emission reduction with respect to the traditional scenario (S.0).

\begin{tabular}{ccc}
\hline \multirow{2}{*}{ Scenario } & \multicolumn{2}{c}{ Annual $\mathbf{C O}_{\mathbf{2}}$ Emission Reduction } \\
\cline { 2 - 3 } & Absence of PV Systems & Presence of PV Systems \\
\hline Comfort & $9 \%$ & $11 \%$ \\
Economy & $10 \%$ & $13 \%$ \\
Energy & $22 \%$ & $45 \%$ \\
Net service & $15 \%$ & $19 \%$ \\
\hline
\end{tabular}

Table 14. Palermo- $\mathrm{CO}_{2}$ emission reduction with respect to the traditional scenario (S.0).

\begin{tabular}{ccc}
\hline \multirow{2}{*}{ Scenario } & \multicolumn{2}{c}{ Annual $\mathbf{C O}_{\mathbf{2}}$ Emission Reduction } \\
\cline { 2 - 3 } & Absence of PV Systems & Presence of PV Systems \\
\hline Comfort & $3 \%$ & $4 \%$ \\
Economy & $13 \%$ & $10 \%$ \\
Energy & $12 \%$ & $32 \%$ \\
Net service & $9 \%$ & $8 \%$ \\
\hline
\end{tabular}


$\mathrm{CO}_{2}$ emission reduction is more visible in the North-where energy consumption for heating during the winter is the highest-and also in the Energy scenario. In this scenario, $\mathrm{CO}_{2}$ emission decreases by $12-32 \%$ and by $32-50 \%$ in the absence and the presence of PV systems, respectively.

As mentioned previously, one of the most important objectives is the postponement of investments for the strengthening and extension of the electricity grid and its components, and thanks to the data obtained from the simulations, some considerations can be made in this regard.

As a simplification hypothesis, it is assumed that the traditional scenario S.0 of year 0 is characterized by the maximum peak value that can be borne by the test network.

The postponement of the investment was calculated considering the scenario of Net-Service for which, by hypothesis, a threshold of the peak power of $2 \mathrm{~kW}$ for each house was guaranteed; for this scenario, an increase of $2 \%$ per year of the total power peak was also considered. Applying this control logic, the power peak decreases by the percentages reported in Table 15 for the three cities. Table 15 also reports the number of years after which the maximum peak is reached after the application of the Net-Service control logic.

Table 15. Percentage reduction of the power peak with respect to scenario SC.0 and deferral time of strengthening measures in years.

\begin{tabular}{cccc}
\hline Indicator & Turin & Rome & Palermo \\
\hline Peak reduction [\%] & $30 \%$ & $20 \%$ & $14 \%$ \\
Deferral time [years] & 18 & 11 & 8 \\
\hline
\end{tabular}

The results obtained depend strongly on the control logic implemented, the action of which is substantially connected to the control of the air-conditioning system. For this reason, the results are infamously influenced by the latitude of the considered position and therefore by the external temperature. Also in this case, the most beneficial effects are visible for Turin.

Lastly, it is worth noting that the present work does not consider the possibility of applying the same control logic to tertiary buildings, which would certainly contribute to a further reduction in overall energy losses and $\mathrm{CO}_{2}$ emissions [33].

\section{Conclusions}

This paper has presented a study focusing on the impact on the LV and MV utility grid, in terms of power peak, $\mathrm{CO}_{2}$ emissions and energy losses reduction, of four control logics suitable for managing electric and thermal loads in residential buildings.

Simulations show the benefits for the electrical power system of such a kind of control, in particular in terms of the deferral of strengthening measures for grids operating close to their maximum capacity. Indeed, DSOs could take advantage of situations of high penetration in a given area of BMS and BAC systems, especially when the BMS is designed for enabling the DSO to directly control the end-users' loads (e.g., the Net-service scenario). Such a function would be in line with the new requirements for distributed generation control both at LV and MV levels [34], reported in the Italian Standards CEI 0-16 and CEI 0-21, that enable the DSO to manage the inverters in specific situations. The current obstacle to this scenario is the still high cost of automation that, as done for PV systems [35,36], needs some specific financial support policies for becoming competitive and a common requirement for residential electrical systems.

Looking at the results of the simulation, with regards to the control logics' effect, the following main conclusions can be drawn:

- different control logics, although acting on the same loads, can produce significantly different effects on the power grid in terms of energy consumption and power losses reduction; 
- the same control logic implemented in the same house but in the presence of different climatic conditions produces significantly different effects both on the power profile of the single house and on the aggregated load profile of the community of end-users.

These results have important implications for the design of future load control logics to be implemented in residential buildings, considering also the new opportunities offered by the flexibility market. In particular, DSOs must carefully consider the impact of the control of air-conditioning systems on the building's electrical power profile and must evaluate this impact, taking into account the specific temperature profile of the area where the grid is located.

Moreover, it is worth noting that the designer that applies the approximate BAC factor method (EN 15232 Standard [37]) for a preliminary evaluation of the energy savings due to automation, should seriously consider the limits of this method. The method, indeed, does not take into account the impact of the external temperature profile that can be very different from city to city and from country to country.

Finally, the control logics considered in this study have not been specifically designed looking at the grid but only pursue some objectives for the single end-user. Therefore, future studies will consider the possibility of taking into account the effects of control logics for clusters of aggregated final end-users [38] for providing services to the DSO in view of economic benefits.

Acknowledgments: The control logics used in this work have been defined within the framework of the National Research Project SIRRCE (System for the residential energy optimization with summer air conditioning intEgration) supported by the Italian Ministry for the Economic Development.

Author Contributions: All the authors gave equal contributions in writing and revising the paper.

Conflicts of Interest: The authors declare no conflict of interest.

\section{References}

1. Amasyali, K.; El-Gohary, N.M. A review of data-driven building energy consumption prediction studies. Renew. Sustain. Energy Rev. 2018, 81, 1192-1205. [CrossRef]

2. Graditi, G.; Ippolito, M.G.; Telaretti, E.; Zizzo, G. Technical and economical assessment of distributed electrochemical storages for load shifting applications: An Italian case study. Renew. Sustain. Energy Rev. 2016, 57, 515-523. [CrossRef]

3. Aydin, C.; Esen, Ö. Does the level of energy intensity matter in the effect of energy consumption on the growth of transition economies? Evidence from dynamic panel threshold analysis. Energy Econ. 2018, 69, 185-195. [CrossRef]

4. Fidalgo, J.N.; Couto, M.; Fournié, L. The worth of network upgrade deferral in distribution systems-Truism or myth? Electr. Power Syst. Res. 2016, 137, 96-103. [CrossRef]

5. Evangelopoulos, V.A.; Georgilakis, P.S.; Hatziargyriou, N.D. Optimal operation of smart distribution networks: A review of models, methods and future research. Electr. Power Syst. Res. 2016, 140, 95-106. [CrossRef]

6. Longe, O.M.; Ouahada, K.; Rimer, S.; Harutyunyan, A.N.; Ferreira, H.C. Distributed Demand Side Management with Battery Storage for Smart Home Energy Scheduling. Sustainability 2017, 9, 120. [CrossRef]

7. Longe, O.M.; Ouahada, K.; Rimer, S.; Ferreira, H.C.; Han Vinck, A.J. Distributed Optimisation Algorithm for Demand Side Management in a Grid-Connected Smart Microgrid. Sustainability 2017, 9, 1088. [CrossRef]

8. Graditi, G.; Ippolito, M.G.; Lamedica, R.; Piccolo, A.; Ruvio, A.; Santini, E.; Siano, P.; Zizzo, G. Innovative control logics for a rational utilization of electric loads and air-conditioning systems in a residential building. Energy Build. 2015, 102, 1-17. [CrossRef]

9. Sabpayakom, N.; Sirisumrannukul, S. Power Losses Reduction and Reliability Improvement in Distribution System with Very Small Power Producers. Energy Procedia 2016, 100, 388-395. [CrossRef]

10. Zongo, O.A.; Oonsivilai, A. Optimal placement of distributed generator for power loss minimization and voltage stability improvement. Energy Procedia 2017, 138, 134-139. [CrossRef]

11. Stoll, B.; Buechler, E.; Hale, E. The value of demand response in Florida. Electr. J. 2017, 30, 57-64. [CrossRef] 
12. Aghaei, J.; Alizadeh, M.; Siano, P.; Heidari, A. Contribution of emergency demand response programs in power system reliability. Energy 2016, 103, 688-696. [CrossRef]

13. Aryandoust, A.; Lilliestam, J. The potential and usefulness of demand response to provide electricity system services. Appl. Energy 2017, 204, 749-766. [CrossRef]

14. Lazzeroni, P.; Olivero, S.; Stirano, F.; Micono, C.; Montaldo, P.; Zanzottera, G.; Calí, F.U.; Repetto, M. Energy efficiency measures for buildings in Hebron city and their expected impacts in the distribution grid. Energy Procedia 2017, 134, 121-130. [CrossRef]

15. NEPLAN. 2018 NEPLAN AG 8700 Küsnacht-Zürich, Switzerland. Available online: http://www.neplan.ch/ (accessed on 8 February 2018).

16. Morvaj, B.; Evins, R.; Carmeliet, J. Decarbonizing the electricity grid: The impact on urban energy systems, distribution grids and district heating potential. Appl. Energy 2017, 191, 125-140. [CrossRef]

17. IEEE. Distribution Test Feeders. Available online: https://ewh.ieee.org/soc/pes/dsacom/testfeeders/ (accessed on 8 February 2018).

18. Morvaj, B.; Evins, R.; Carmeliet, J. Optimization framework for distributed energy systems with integrated electrical grid constraints. Appl. Energy 2016, 171, 296-313. [CrossRef]

19. Faessler, B.; Schuler, M.; Preißinger, M.; Kepplinger, P. Battery Storage Systems as Grid-Balancing Measure in Low-Voltage Distribution Grids with Distributed Generation. Energies 2017, 10, 2161. [CrossRef]

20. Lawder, M.T.; Suthar, B.; Northrop, P.W.C.; De, S.; Hoff, C.M.; Leitermann, O.; Crow, M.L.; Santhanagopalan, S.; Subramanian, V.R. Battery Energy Storage System (BESS) and Battery Management System (BMS) for Grid-Scale Applications. Proc. IEEE 2014, 102, 1014-1030. [CrossRef]

21. Chen, H.; Cong, T.N.; Yang, W.; Tan, C.; Li, Y.; Ding, Y. Progress in electrical energy storage system: A critical review. Prog. Nat. Sci. 2009, 19, 291-312. [CrossRef]

22. Fäßler, B.; Kepplinger, P.; Kolhe, M.L.; Petrasch, J. Decentralized on-Site Optimization of a Battery Storage System Using One-Way Communication; Institution of Engineering and Technology: Stevenage, UK, 2015; pp. 1-7.

23. Faessler, B.; Kepplinger, P.; Petrasch, J. Decentralized price-driven grid balancing via repurposed electric vehicle batteries. Energy 2017, 118, 446-455. [CrossRef]

24. Muruganantham, B.; Gnanadass, R.; Padhy, N.P. Challenges with renewable energy sources and storage in practical distribution systems. Renew. Sustain. Energy Rev. 2017, 73, 125-134. [CrossRef]

25. Wang, Y.; Shi, W.; Chu, C.; Gadh, R. Optimal operation of stationary and mobile batteries in distribution grids. Appl. Energy 2017, 190, 1289-1301. [CrossRef]

26. Jensen, S.O.; Marszal-Pomianowska, A.; Lollini, R.; Pasut, W.; Knotzer, A.; Engelmann, P.; Stafford, A.; Reynders, G. IEA EBC Annex 67 Energy Flexible Buildings. Energy Build. 2017, 155, 25-34. [CrossRef]

27. Favuzza, S.; La Cascia, D.; Ippolito, M.G.; Massaro, F.; Zizzo, G. On the Effects of BAC Systems and Load Control Programs on the Utility Grid. In Proceedings of the 2017 IEEE International Conference on Environment and Electrical Engineering, EEEIC 2017, Milan, Italy, 6-9 June 2017; pp. 1-5.

28. Italian Standard UNI 10349, Heating and Cooling of Buildings_Climatic Data; UNI: Milano, Italy, 2016.

29. D.P.R. n. 412, Regolamento Recante Norme per la Progettazione, L'installazione, L'esercizio e la Manutenzione Degli Impianti Termici Degli Edifici ai Fini del Contenimento dei Consumi di Energia, in Attuazione dell'art. 4, comma 4, della L. 9 Gennaio 1991; n. 10; Gazzetta Ufficiale: Roma, Italy, 1993. (In Italian)

30. JRC Photovoltaic Geographical Information System (PVGIS)—Geographical Assessment of Solar Resource and Performance of Photovoltaic Technology. Available online: http://re.jrc.ec.europa.eu/pvgis/ (accessed on 16 May 2017).

31. AEGGSI Deliberation n. 119/06-Annex A, Testo Integrato delle Disposizioni dell'Autorità per l'Energia Elettrica e il Gas per l'Erogazione dei Servizi di Vendita Dell'energia Elettrica di Maggior Tutela e di Salvaguardia ai Clienti Finali ai Sensi del Decreto Legge 18 Giugno 2007; n. 73/07; ARERA: Milan, Italy, 2007. (In Italian)

32. ISPRA Database. Available online: http://www.sinanet.isprambiente.it/it/sia-ispra/inventaria (accessed on 16 May 2017).

33. Grasselli, U.; Lamedica, R.; Ruvio, A.; Novati, D. Management policies for residential and tertiary users: A measurement campaign. In Proceedings of the 2014 International Symposium on Power Electronics, Electrical Drives, Automation and Motion, SPEEDAM 2014, Ischia, Italy, 18-20 June 2014; pp. 1290-1295. 
34. Di Silvestre, M.L.; Graditi, G.; Ippolito, M.G.; Riva Sanseverino, E.; Zizzo, G. Robust multi-objective optimal dispatch of distributed energy resources in micro-grids. In Proceedings of the 2011 IEEE PES Trondheim PowerTech: The Power of Technology for a Sustainable Society, POWERTECH 2011, Trondheim, Norway, 19-23 June 2011; pp. 1-5.

35. Dusonchet, L.; Favuzza, S.; Massaro, F.; Morello, G. Analisi economico-finanziaria degli investimenti sul fotovoltaico in Italia. L'Energia Elettrica 2009, 86, 37-51.

36. Di Dio, V.; Favuzza, S.; La Cascia, D.; Massaro, F.; Zizzo, G. Critical assessment of support for the evolution of photovoltaics and feed-in tariff(s) in Italy. Sustain. Energy Technol. Assess. 2015, 9, 95-104. [CrossRef]

37. EN Standard 15232:2017, Energy Performance of Buildings. Impact of Building Automation, Controls and Building Management; European Standard: Brussels, Belgium, 2017.

38. Favuzza, S.; Galioto, G.; Ippolito, M.G.; Massaro, F.; Milazzo, F.; Pecoraro, G.; Riva Sanseverino, E.; Telaretti, E. Real-time pricing for aggregates energy resources in the Italian energy market. Energy 2015, 87, 251-258. [CrossRef]

(C) 2018 by the authors. Licensee MDPI, Basel, Switzerland. This article is an open access article distributed under the terms and conditions of the Creative Commons Attribution (CC BY) license (http://creativecommons.org/licenses/by/4.0/). 